\title{
Sustainable Chemistry: Green Chemistry
}

\author{
Zafer KARAGÖLGE', Bahri GÜR²
}

ABSTRACT: Our living standard rose after the industrial revolution. It developed many products that facilitate life, to extend human life. Industrial revolution has brought increased production with it. Increased production but also as a source (raw material) made to be consumed rapidly. However, no one; neither consumers nor scientists, nor some toxic industrial companies could think that thousands tons of waste contaminate air, water and soil. Only the success of the work done was measured in the linear structure of the economy without looking at the heritages it has left. Soon, serious environmental problems and industry associations, waste affecting the ecosystem could not ignore more. Waste reduction, reuse and recycling green movement started with my community's increasing awareness of nature conservation, sustainability has spread in waves with the slogan to become one of the 20th century. Chemical area was also affected by the current green chemistry research in the 1990s and came to fruition with the production and training projects. Chemical industry using the principles of green chemistry began to take measures relating to sustainability and the environment. For a continually growing population and restricted resources in a sustainable future in a world where the idea of the idea of development in the 21 st century is one of the biggest opinions of green chemistry. It is significant to understand the principles of green chemistry and green chemistry, to leave a livable world for future generations and to apply.

Keywords: Chemical pollution, green chemistry, livable environment, sustainability

\section{Sürdürülebilir Kimya: Yeşil Kimya}

ÖZET: Sanayi devriminden sonra yaşam standartlarımız yükseldi ve hayatımızı kolaylaştıran birçok yeni ürün geliştirildi, insan ömrü uzadı. Endüstri devrimi ile birlikte ihtiyaçlarımızla orantılı olarak üretim artmış ve bu üretim artışı ham maddelerin hızla tüketilmesine yol açmıştır. Maalesef; ne tüketicilerin, ne üreticilerin, ne bilim insanlarının ne de sanayi kuruluşlarının aklına bu üretim prosesleri sonucunda açığa çıkan bazısı zehirli ve bazısı zararlı, binlerce tonluk endüstriyel atığın havaya, suya ve toprağa karıştığı gelmedi. Fabrikaların üretim verimliliği ve elde edilen kâr başarı olarak ele alınırken, çevreye verdikleri zarar göz ardı edildi. Bunun sonucu olarak çeşitli çevre sorunları ortaya çıkmaya başladı ve sanayi kuruluşları, ekosistemi etkileyen bu çevre sorunlarını daha fazla görmezlikten gelemediler. Atıkların bertaraf edilmesi ve geri dönüşümüyle başlayan yeşil kimya hareketi, toplumda çevre bilincinin artması ve sürdürülebilirliğin bir slogan olarak yayılmasını sağlamıştır. Kimya alanı da bu akımdan etkilendi ve 1990'larda yeşil kimya araştırma, üretim ve eğitim projeleriyle çiçek açtı. Kimya endüstrisi yeşil kimyanın ilkelerini kullanarak, sürdürülebilirlik ve çevre ile ilgili önlemler almaya başladı. Sürekli olarak artan bir nüfus ve sınırlı kaynaklarla bir dünyada sürdürülebilir bir kalkınma fikri düşüncesi gelecek için 21. yüzyıldaki en büyük düşüncelerden biri yeşil kimyadır. Gelecek nesillere yaşanabilir bir dünya bırakmak için yeşil kimya ve yeşil kimyanın ilkelerini anlamak ve uygulamak önemlidir.

Anahtar kelimeler: Kimyasal kirlilik, sürdürülebilirlik, yaşanabilir çevre, yeşil kimya

Atatürk Üniversity, Kazım Karabekir Education Faculty, Chemistry Education, Erzurum, Turkey

Iğdır University, Health Services Vocational School, Medical Services and Techniques, Iğdır, Turkey Sorumlu yazar/Corresponding Author: Zafer KARAGÖLGE, zaferk@atauni.edu.tr 


\section{INTRODUCTION}

Chemistry has become an important contributor of everyday life during last the century. Among the numerous use of chemistry in everyday life, greatest input for public life comes from the pharmaceuticals industry with developments of painkillers, antibiotics, heart drugs and, more newly, Viagra. It is almost impossible to see any fact of the modern life that was not affected from the products of chemical and related industries Table 1 (Lancaster, 2002).

Table 1. Application of chemistry in different industrial fields

\begin{tabular}{|l|l|}
\hline Application Fields & \multicolumn{1}{c|}{ Examples } \\
\hline Carrying Trade & $\begin{array}{l}\text { Manufacture of gas and diesel from petroleum, combustible additives for greater yield and } \\
\text { decreased emissions, catalytic converters, plastics to decrease vehicle weight and improve } \\
\text { energy yield }\end{array}$ \\
\hline Dress & $\begin{array}{l}\text { Man-made fibers such as rayon and nylon, paints, watertight and other surface finishing } \\
\text { chemicals }\end{array}$ \\
\hline Sports & Developed composite materials for tennis and squash rackets, all-weather surfaces \\
\hline Security & Lightweight polycarbonate cycle hard hats, flame-retardant furnishing \\
\hline Nutrition & Coolers, packaging, containers and wraps, nutrition processing aids, preserver \\
\hline Medicinal & $\begin{array}{l}\text { Synthetic joints, "blood bags", anesthetics, disinfectants, anti-cancer medicines, vaccinations, } \\
\text { dental cores, contact lenses, contraceptives }\end{array}$ \\
\hline Office & Photocopying toner, inks, printed circuit boards, liquid crystal screen \\
\hline House & $\begin{array}{l}\text { Material and paints for rugs, plastics for TVs and mobile telephones, CDs, video and sound } \\
\text { bands, dyes, cleaners }\end{array}$ \\
\hline Agriculture & Fertilizers, pesticides \\
\hline
\end{tabular}

Chemical industry, with many chemical manufacturing processes and products, nutrition, as well as the basic requirements such areas as housing, health, computing, is an industry that provides the input to the fields requiring high technology such as telecommunications and biotechnology. Owing to the nature of the chemical industry, as well as to areas where their own space related, must be continuously improved the technology required for the production of products, and this product. In short, chemical production has to be based on continuous research and development (R\&D). In recent years, the world of scientific research conducted on chemical nanotechnology, biochemistry, catalysts, genetics, organic and polymer chemistry (TÜBİTAK, 2003).
World chemical industry export in 2013 has mounted to about 5.1 trillion US dollars, which is $28.9 \%$ of total world export (18 billion US dollars). In the same year, chemical industry import stood at US \$ 5.5 trillion, which was $29.3 \%$ of the world's total and the world's total import was 18.7 billion US dollars (ITC Trademap, 2014).

The chemical industry accounts for $7 \%$ of global income and $9 \%$ of global commerce, adding up to US $\$ 1.5$ trillion in sales in 1998 , with $80 \%$ of the world's output produced by 16 countries. Production is projected to rise $85 \%$ by 2020 compared to the 1995 levels (Doble et al., 2007).

Towards the end of the 20th century, population growth, depletion of natural resources and developments 
in the chemical industry has emerged as the most important environmental problems. Especially future concerns have led people to take precautions. These measures are concentrated in the chemical industry, which is a sine qua non of the industry.

In recent years, the chemical industry of the "image" precisely where the problem is. Although the steps taken forward in reducing pollution, public relations departments to work in strict entry if people think primarily smoking chimneys, polluted rivers and sounds of fire or explosion hazard. Unfortunately chemical plant toxic (poisonous) and they do not get rid of that image as long as they continue to use mainly flammable organic solvents. In addition, the increase in the world population and life the rise in the standard (at least in one part of the world) there are no barriers to sustainable chemical production methods. Production to meet increasing demand is rising day by day with the increasing levels of waste. In this case the difference chemists who they think the need for a new approach. Therefore roll up their sleeves, environmentally friendly "green" chemistry to the understanding of our lives trying added. As little harm to the environment and therefore require less regulation in the production of green chemistry, pollution, adopting some principles aimed at minimizing. In fact, none of these principles is not new; new is combining these first (Y1lmaz, 2001).

Although chemistry is helping enormously to the quality of life, negative effect of some chemicals are not exactly know to the human health and environment, even though they have been in use for several decades. There is about $\$ 30$ billion spending each year on research and development in environmental (R\&D). As shown by Doble and Kruthiventi (2007) in Figure1 process for an ideal manufacturing has to have some criterion.

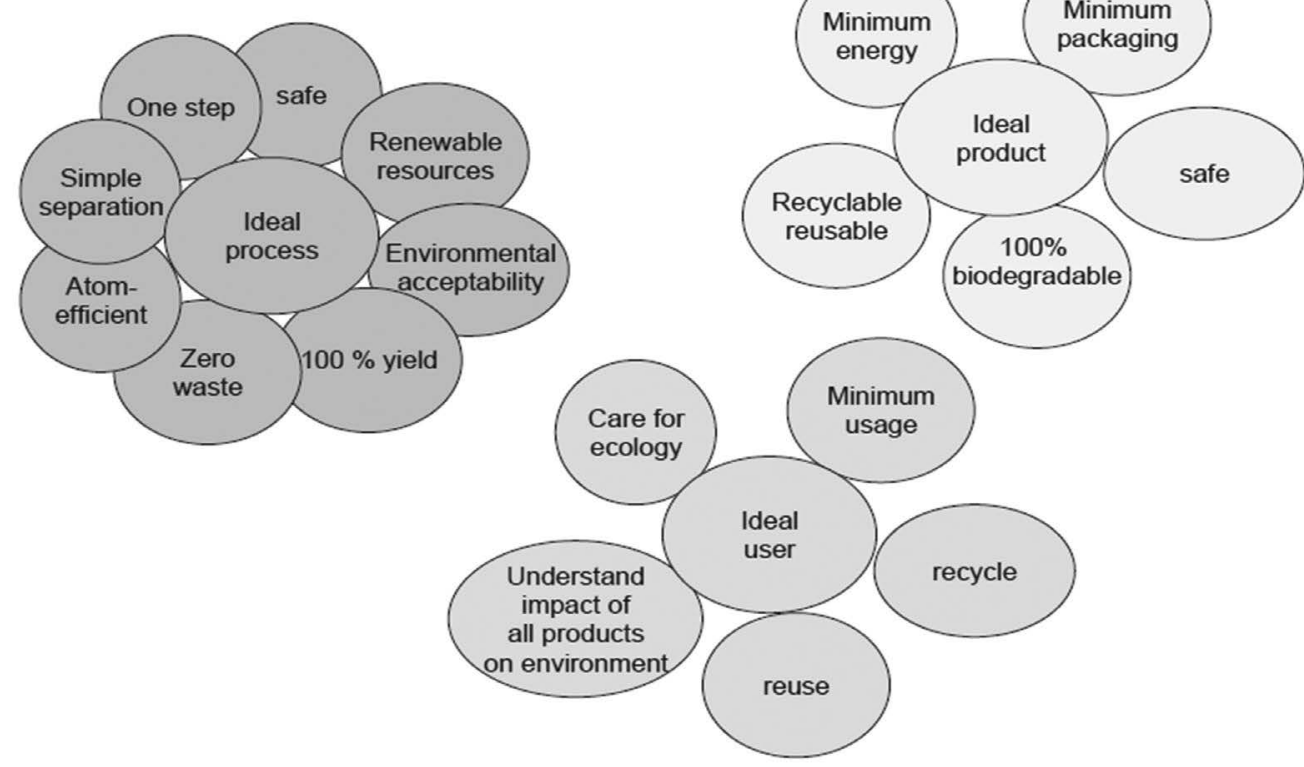

Figure 1. Criteria for ideal product, process of manufacture and user (Doble et al., 2007)

An optimal process is fundamental, wants only a step, is safe, consumes renewable resources, is environmentally plausible, has total outcome, produces no waste at all, is atom-efficient, and occur basic separation techniques. An optimal product needs less energy and less packaging, is safe and fully biodegradable, and is recyclable. Usually, the public gives emphasis on the procedure and produce, giving very small care to the "ideal user." Figure1 also shows the characteristics of an ideal user. An ideal 
user pays attention to the environment, consumes least amounts, recycles, reuses, and understands a product's environmental effect and encourages "green" attempts (Dobl et al., 2007).

One of the biggest problems today's World of environmental pollution, environmental pollution is one of the biggest causes of nature thrown chemicals, toxic gases drained from factory chimneys, water, mixed solvents. Displays on the rapidly growing environmental pollution by the most responsible as chemicals, chemists and chemical engineers began looking at alternative solutions. The most significant of alternative ways to reach a sustainable improvement in a world with a continually growing population and restricted resources is green chemistry.

Green chemistry aims to less use or avoid using hazardous substances in a chemical process. In fact green chemistry is a movement to find alternatives to the use of hazardous chemicals such as feedstock, reagents, solvents, products, and byproducts in the production processes. Moreover, it concerns about sustainability of using raw materials and energy sources for manufacturing (Anastas and Warner, 1998; Anastas and Lankey, 2000; Anastas et al., 2001; Anastas and Lankey, 2002).

Green chemistry (EPA, 2016):

Prevent pollution at the molecular level,

Chemistry is not in one area, it is a philosophy that applies in all areas,

The world's environmental problems applies innovative scientific solutions,

Helps to reduce the sources by preventing the generation of pollution,

Reducing human health and the environment on the negative impact of chemical products and processes,

Eliminates the danger of existing products and processes,

is to decrease the hazards of chemical products and processes to design new methods.

\section{History of Green Chemistry}

US Environmental Protection Agency (EPA) started to use the term green chemistry to implement a sustainable reconstruction in chemistry and chemical technology by industry, academia and government. At the same the annual US Presidential Green Chemistry Challenge was initiated in 1995. Europe was followed in establishing similar awards. On the other hand International Union of Pure and Applied Chemistry (IUPAC) set a Working Party on Green Chemistry. Almost a year after this IUPAC initiative, the Green Chemistry Institute (GCI) was founded with branches in different countries to facilitate contact between governmental, industry, academia and research institutes. Meanwhile conferences initiated in green chemistry first time in 1997 in Washington become a regular academic endeavor. In 1990s, first books and journals on green chemistry come out, among them, Journal of Clean Processes and Products by SpringerVerlag and Green Chemistry by the Royal Society of Chemistry are well known journals. However, some other journals, such as Environmental Science and Technology and the Journal of Chemical Education, also devoted sections to green chemistry (Wardencki, Curyo and Namieoenik, 2005).

\section{The 12 Principles of Green Chemistry}

After the definition of green chemistry, the head of the Green Chemistry Institute of the University of Massachusetts Paul T. Anastas and John C. Warner twelve principles of green chemistry approach it identified. These principles, who will work on this issue guidance, feature (Anastas and Warner, 1998). The 12 principles of green chemistry is given in Table 2 . 
Table 2. The 12 principles of green chemistry

\begin{tabular}{|c|c|}
\hline Number & Properties \\
\hline 1. & Prevent waste: It is more effective not to produce waste than to treat or clean it up after it has been produced. \\
\hline 2. & $\begin{array}{l}\text { Atom economy: Synthetic procedures should be planned to optimize the incorporation of all substances used in the } \\
\text { process into the final product. }\end{array}$ \\
\hline 3. & $\begin{array}{l}\text { Design less dangerous chemical syntheses: Wherever pragmatic, synthetic procedures } \\
\text { should be figured to use and manufacture materials that cause little or zero toxicity to people } \\
\text { or the environment. }\end{array}$ \\
\hline 4. & $\begin{array}{l}\text { Produce safer chemicals and products: Chemical products should be produced to conduct } \\
\text { their coveted function while minimizing their perniciousness. }\end{array}$ \\
\hline 5. & $\begin{array}{l}\text { Safer solvents and auxiliaries' substances: The use of auxiliary substances (e.g., solvents or separation agents) } \\
\text { should be made unnecessary whenever possible and innocuous when used. }\end{array}$ \\
\hline 6. & $\begin{array}{l}\text { Increase energy efficiency: Energy requirements of chemical procedures should be distinguished for their } \\
\text { environmental and economic effects and should be minimized. If possible, synthetic procedures should be carried } \\
\text { out at environmental temperature and pressure. }\end{array}$ \\
\hline 7. & $\begin{array}{l}\text { Use renewable feedstocks: A raw material or feedstock should be renewable rather than consumed whenever } \\
\text { technically and economically pragmatic. }\end{array}$ \\
\hline 8. & $\begin{array}{l}\text { Avoid chemical derivatives: Not needed derivatization (use of blocking groups, protection- } \\
\text { protection, and not permanent alteration of physical chemical procedures) should be minimized or refrained if } \\
\text { possible, because such steps need extra reagents and can produce waste. }\end{array}$ \\
\hline 9. & $\begin{array}{l}\text { Use catalysts, not stoichiometric reagents: Catalytic reagents (as optional as possible) are high to stoichiometric } \\
\text { reagents. }\end{array}$ \\
\hline 10. & $\begin{array}{l}\text { Produce chemical substances and products to be reduced after use: Chemical products should be produced } \\
\text { so that after their function they decay into harmless degradation products and do not last for long time in the } \\
\text { environment. }\end{array}$ \\
\hline 11. & $\begin{array}{l}\text { Analyse in real time to prevent contamination: Analytical methodologies are necessary to } \\
\text { be further advanced to enable for real-time, in-process tracking and control prior to the formation of harmful } \\
\text { substances. }\end{array}$ \\
\hline 12. & $\begin{array}{l}\text { Minimize the potential for accidents: Substances and the form of a substance used in a chemical procedure should } \\
\text { be selected to minimize the risk of chemical accidents, including releases, explosions, and fires. }\end{array}$ \\
\hline
\end{tabular}

As seen from the Table 2, five main foci emerge from these 12 principles namely; less, safe, process- oriented, waste-reducing, sustainable, respectively

(Doble et al., 2007).

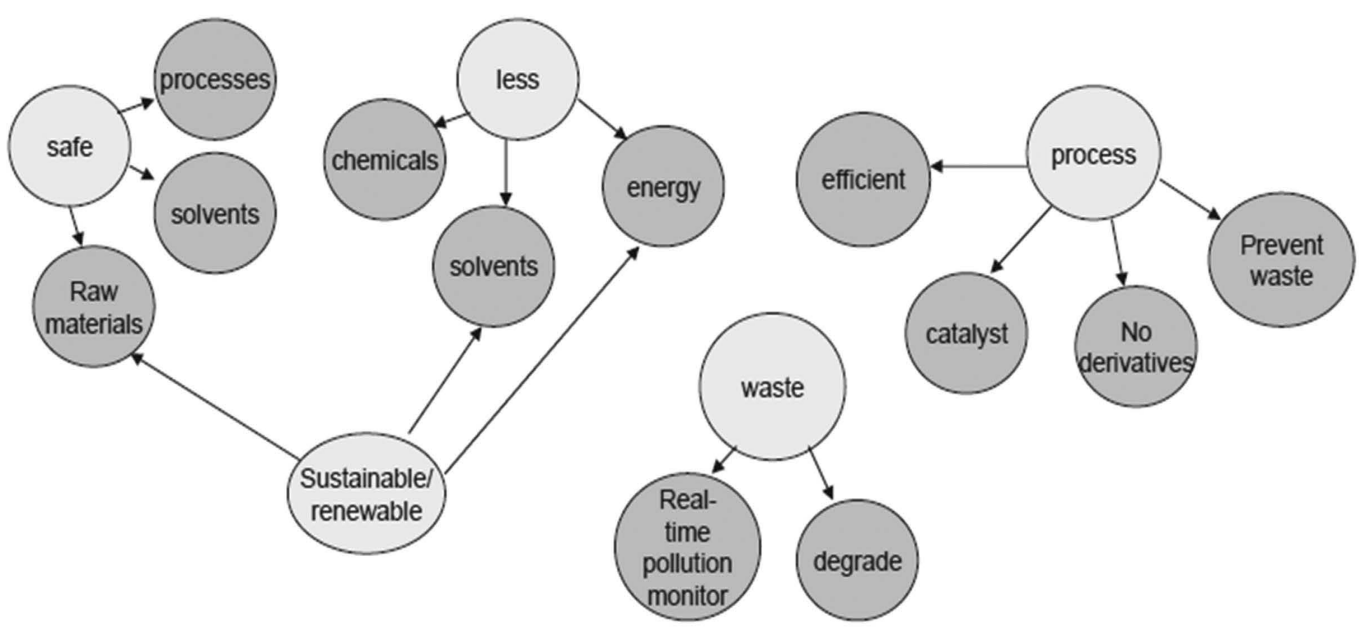

Figure 2. Spanner words in 12 principles of green chemistry (Doble et al., 2007) 
Whole five key words could be grouped round this, as shown in Figure2. The principles of green chemistry are (1) Uses less chemical substances, solvents, and energy, (2) Has safer raw materials, procedures, and solvents, (3) Processes should be effective and useful, without unnecessary formation of chemical compounds into products, and catalysts should be used during the processes, (4) Waste produced should be constantly observed in real time and should be taken down, (5) All chemicals, raw materials, solvents, and energy should be renewable or sustainable (Doble et al., 2007).

The main philosophy of green chemistry was represented by the five key words during process development. These can be seen in Figure2 (Doble et al., 2007).

An alternative term to the green chemistry is Sustainable Technologies. Sustainable development has been defined as (Brundtland, 1987).

Sustainability in the chemistry could be achieved throug Green Chemistry ( Sheldon et al., 2007)

The R\&D of green chemistry has been defined by a group of scientists in 2000. These are: Use of alternating feedstocks: Use of feedstocks that are renewable, rather than reducing, and less poisonous to people and the environment; use of harmless reagents: Use of reagents, which are naturally less dangerous and are catalytic whenever probable; employing natural procedures: Use of biosynthesis, biocatalysis, and biotechbased chemical transformations for higher yield and particularity; use of alternating solvents: Production and use of solvents that have decreased risk of harm to the environment and serve as alternatives to already used volatile organic solvents, chlorinated solvents, and solvents that harm the environment; production of safer chemicals: Use of molecular structure design and thinking of the bases of perniciousness and mechanism of action to minimize the actual perniciousness of the product while sustaining its benefits of function; developing alternating reaction requirements: Production of reaction requirements that improve the particularity of the product and enable dematerialization of the product separation technique; minimizing energy use: Production of chemical transformations that reduce the energy input needed in terms of both mechanical and thermal inputs and the related environmental effects of excessive energy use (Tundo et al., 2000).

\section{Benefits of Green Chemistry}

Green Chemistry provides less waste formation addition to offering appropriate solutions in the field of economy and energy; they also reduce the risk of accidents because the front legs of the advancing reaction to the presence of a safe way. Overall this is a new approach to ensure preservation of human health and the environment; the world will play an active role in the prevention of environmental pollution in our country and is actively used in various applications. We see that there are many benefits of green chemistry. These advantages, human health, environment and economy may be described as subtitles, respectively. Human health, environmental and economic advantages were given in Table 3 (EPA, 2016). 
Table 3. Green chemistry, human health, environmental and economic benefits of the fields.

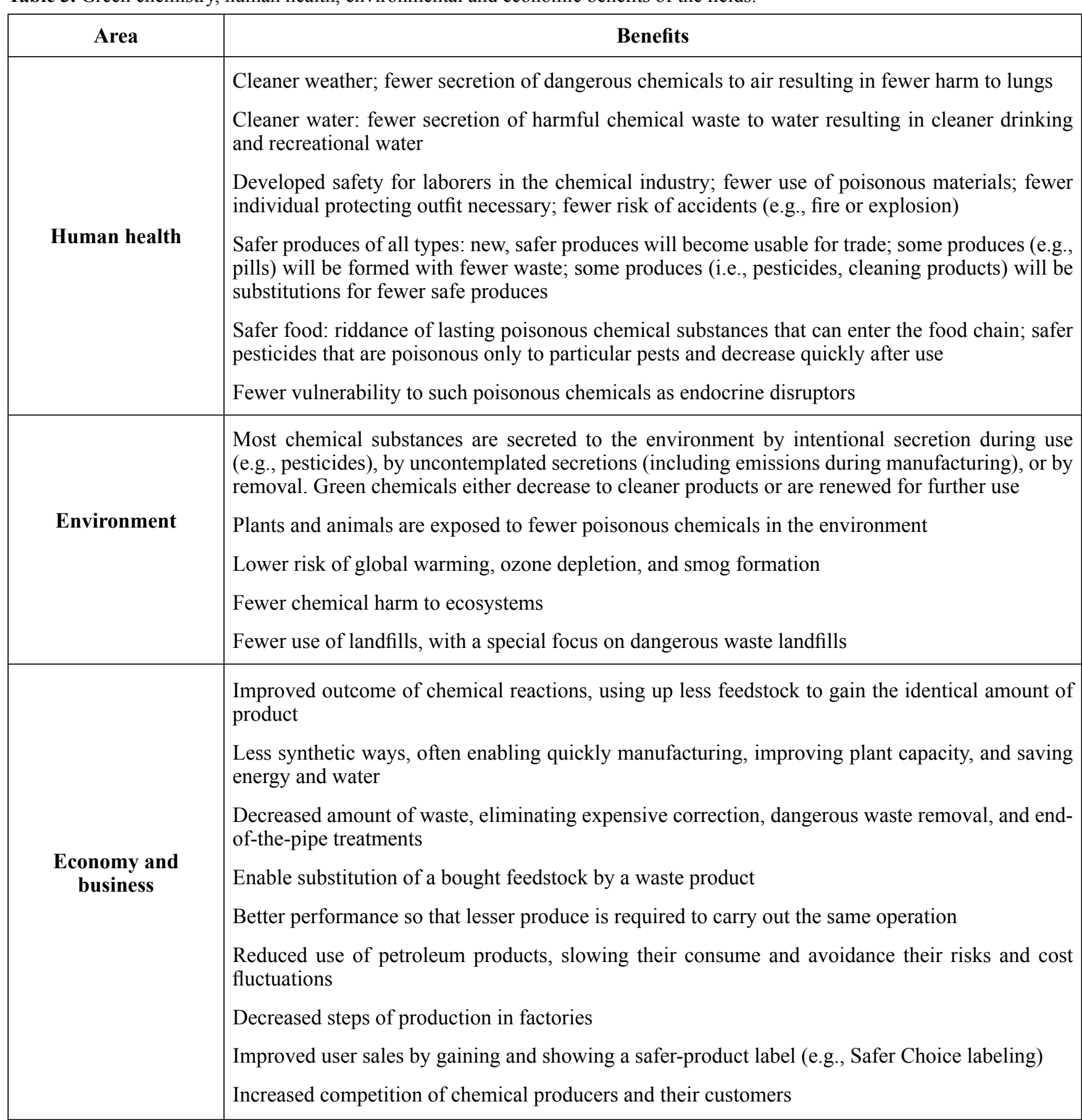

\section{CONCLUSION}

When considering today's conditions, key concepts such as some endangered resources, wastes that pollute the environment, waste reduction methods, use of renewable energy sources and life cycle analysis has become increasingly important. It should be considered that green chemistry can be used for a sustainable future in the globalized world. In this case, the engineers of the future are expected to design sustainable products and processes (Davidson et al., 2010).

Because green chemistry solutions to environmental problems at the atomic and molecular level is essential for sustainable development it is one of the key. Green chemistry aims to develop new practice of chemistry with rules which provides resolutions to problems that human is facing today such as climate changes, 
sustainable farming, energy need, toxics, consuming of natural sources e.g. designing new chemicals and processes that production and use of dangerous matters. Therefore green chemistry is an indispensable tool for sustainable development. As a chemist we need to consider the human health and ecological issues in our professional life (Gerçek, 2012). For a continually increasing population and restricted resources in a sustainable future in a world where the idea of the idea of development in the 21 st century is one of the biggest ideas of green chemistry. Green Chemistry is a science that aims to emphasize the development of chemical methods and substances to protect the environment. Green chemistry provides economic benefits to be obtained by performing the reaction of the new reality will reduce production costs and saving energy at lower temperatures for the actual design highly efficient reactions.

Green Chemistry provides less waste formation addition to offering appropriate solutions in the field of economy and energy; they also reduce the risk of accidents because the front legs of the advancing reaction to the presence of a safe way. Overall this is a new approach to ensure preservation of human health and the environment; the world will play an active role in the prevention of pollution in our country and is actively used in various applications.

It is significant to understand the principles of green chemistry and green chemistry, to leave a livable world for future generations and to apply.

In order to establish a sustainable future for the green chemistry, it would be better to inteprote its principles and practices in every chemicals sciences degree courses. By this way future generations will be informed about it (Clark, 2006).

\section{REFERENCES}

Anastas PT, Warner JC, 1998. Green Chemistry, Theory and Practice. First Edition, Oxford University Press: Oxford, UK. $148 \mathrm{p}$.

Anastas PT, Lankey RT, 2000. Life cycle assessment and green chemistry: the yin and yang of industrial ecology. Green Chem. 2:289-295.

Anastas PT, Kirchhoff MM, Williamson TC, 2001. Catalysis as a foundational pillar of green chemistry. Appl. Catal. A: Gen. 221: $3-13$.
Anastas PT and Lankey RL, 2002. Sustainability through green chemistry and engineering, ACS Symp. Series, 823: 1-11.

Brundtland CG, 1987. Our Common Future, The World Commission on Environmental Development. First Edition. Oxford University Press, Oxford, UK, 400 p.

Clark JH, 2006. Green chemistry: today (and tomorrow). Green Chem. 8: 17-21.

Davidson CI, Hendrickson CT, Matthews HS, Bridges MW, Allen DT, Murphy CF, Allenby BR, Crittenden JC, Sharon Austin $\mathrm{S}$, 2010. Preparing future engineers for challenges of the 21st century: Sustainable engineering. Journal of Cleaner Production, 18: 698-701.

Doble M, Kruthiventi AK, 2007. Green Chemistry and Engineering. 1 st Edition, Academic Press is an imprint of Elsevier, $344 \mathrm{p}$.

EPA, (United States Environmental Protection Agency) 2016. http:// www.epa.gov/greenchemistry /benefits-green-chemistry (Erişim tarihi: 11 Şubat, 2016)

Gerçek Z, 2012. Kimya'nın Yeni Rengi: Yeşil Kimya; The New Color of Chemistry: Green Chemistry. Yükseköğretim ve Bilim Dergisi/Journal of Higher Education and Science, 2(1): 50-53.

ITC Trademap, 2014. TC Ekonomi Bakanlığı Kimya Sektörü, Sektör Raporları. İhracat Genel Müdürlüğü, Kimya Ürünleri ve Özel İhracat Genel Müdürlüğü.

Lancaster M, 2002. Green Chemistry: An Introductory Text. First Edition. Royal Society of Chemistry, Cambridge, England, $238 \mathrm{p}$.

Sheldon RA, Arends I, Hanefeld U, 2007. Green Chemistry and Catalysis. First Edition, WILEY-VCH Verlag GmbH \& Co. KGaA, Weinheim, Germany. 434 p.

Tundo P, Anastas P, StC. Black D, Breen J, Collins T, Memoli S, Miyamoto J, Polyakoff M, and Tumas W, 2000. Synthetic pathways and processes in green chemistry. Introductory overview. Pure and Applied Chemistry, 72:1207-28.

TÜBİTAK, 2003. Vizyon 2023 Teknoloji Öngörü Projesi Kimya Paneli Raporu Temmuz, TÜBİTAK, Ankara.

Wardencki W, Curyo j, Namieoenik J, 2005. Green ChemistryCurrent and Future Issues, Polish Journal of Environmental Studies 14(4): 389-395.

Yılmaz T, 2001. Kimya Endüstrisine Bahar Geliyor Yeşil Kimya. TÜBİTAK Bilim ve Teknik Dergisi, Kasım 2001, 91-97. 